\title{
Speech Act Thoughts in Pierre Bourdieu's Economics of Linguistic Exchanges
}

\author{
Cunjiu Kuang1, a \\ ${ }^{1}$ College of Humanities, Sichuan Agricultural University, Ya’an, Sichuan Province, 625104, China
}

${ }^{a}$ Email: 476033678@qq.com

Keywords: Bourdieu; economics of linguistic exchanges; speech act theory

\begin{abstract}
Based on Austin's and Searle's speech act theory, Bourdieu focuses on the combination of language and power, integrates with political studies, symbolically regards the entire society as a language-mediated exchange market, and holds that speech acts play an essential role of communication and mediation in the entire linguistic social market, based on which, the well-known theory of "economics of linguistic exchanges" has been proposed.
\end{abstract}

\section{Speech Acts and Cultural Performative}

The theory of social practice proposed Pierre Bourdieu (1930-2002) has been positively affected by John Searle's speech act theory. Yuan Guohua, a Chinese scholar, believes that John Searle's speech act theory is one of the important sources of thoughts in Bourdieu's theory of economics of linguistic exchanges. It can be discovered that Bourdieu, based on Austen's and Searle's speech act theory, pays attention to the integration of language and power, also integrates with political research, and puts forward the famous theory of "economics of linguistic exchanges". Some foreign scholars have even exclusively compared Searle's and Bourdieu's thoughts. He takes the research of speech acts as his own responsibility, and regards the development of Austin's speech act theory as his representative work. He expressed with deep feelings: "We must be grateful to philosophers of language, and particularly to Austin, for having asked how it is that we can 'do things with words', that utterances can produce effects”. Therefore, his theoretical starting point is no longer a linguistic self-performative, but more of a performative of cultural power or social relationship. For him, all sociological theories "must take account of ... the contribution they make to the construction of the vision of this world, and, thereby to the very construction of this world". Speech acts impose their own vision of the world or the vision of their own position in this world, that is, their social identity, through the labor of representation, making utterances a reality. For him, valid discourses are a creative speech that establishes what it utters. Every speech act is actually a combination of events, a series of independent causal encounters. In fact, speech acts can also create this fact through utterances, prophecies or imagination and so on especially the collective representations, wishes, etc. that are believed. They are the ultimate goal to be achieved by all the performative utterances, such as prayer, curses, commands, wishes or humiliation. In specific research, Bourdieu, from time to time, explores the ideas of social relations or institutional acts from Austin's own expounding. Similar to Searle's view that speech acts play an important fundamental role in language communication and social reality construction, Bourdieu regards the entire society symbolically as a language-mediated exchange market, namely, a "market of linguistic exchanges". It can be discovered that, speech acts play an essential role in communication and mediation on the entire market of linguistic exchanges, which share many similarities with Searle's speech act theory, especially the research of social reality and institutional facts.

From the perspective of sociology, Bourdieu pays special attention to the ideas of social relations and institutional acts from Austin's and Searle's speech act theory. For him, Austin's expounding of performative utterances can not be limited to the linguistic aspect. On the one hand, he criticizes Austin's practice of exclusively pragmatic or linguistic analysis; on the other hand, he seeks clues on social studies from Austin's and Searle's own expounding. For him, although Austin clearly points out that effectiveness of symbols depends on institutional conditions, he does not analyze the social 
characteristics of these institutional conditions including actors, time, place, authority, etc., but retreats to differentiation at the linguistic level, dividing speech acts into categories such as "locutionary acts", "perlocutionary act", and "illocutionary acts". It can be said that, the limitation of Austin's definition of performative utterances is that he failed to do what he thought he was doing, and he did not carry through it firmly to the end. Objectively speaking, Austin actually gives institutions a core position when analyzing language, and many of his commentators have misinterpreted his expounding and focused on the intrinsic nature of language instead. For example, Austin's analysis of ceremonies such as the naming of ships and the baptism, including his discussion of "felicity conditions", involves factors such as the identity, status, authority, etc. of the performer, which can be regarded as some analyses of social conditions, institutional acts, super-linguistic acts, etc. Searle has inherited Austin's views, and, in his discussions about speech acts and their standards in as early as the 1960s and the 1970s, he mentioned that, the identities or statuses of the speaker and the listener would affect the illocutionary force of speeches; he also held that, the performance of some speech acts would entail some "extra-linguistic institutions", i.e. "requiring the speaker and the listener to have a special status in that institution". Bourdieu conceptualizes Searle's "extra-linguistic institutions" into a certain "mystery of ministry" or a "group" that acts; for him, "the real source of the magic of performative utterances lies in the mystery of ministry, i.e. the delegation by virtue of which an individual - king, priest or spokesperson - is mandated to speak and act on behalf of a group, thus constituted in him and by him. More precisely, it lies in the social conditions of the institution of the ministry, which constitutes the legitimate representative as an agent capable of acting on the social world through words, by instituting him as a medium between the group and the social world; and it does that, among other things, by equipping him with the signs and the insignia aimed at underlining the fact that he is not acting in his own name and under his own authority." Against the background of "ministry", "institution" and "group”, Bourdieu notes that, it is the power or "authority" that speaks, not the speaker who speaks, which is somewhat metaphorical and symbolical.

Similarly, based on his understanding of Austin's and Searle's authority of performative utterance and extra-linguistic institutions, Bourdieu believes that Austin and Searle had actually created a set of symbolic expression theory of a particular class. For Austin, speech acts can both state facts or describe the state of things, and can also perform acts and actions. In Bourdieu's view, the main reason lies in that speech acts accumulate the symbolic capital of the group, that is, elect him the authority representative to master the symbolic capital accumulated by the group. It can be found that Searle's concept of status function of institutional facts has become a symbolic capital for Bourdieu; giving an entity the status function is to create the possibility for this entity. From the discussions of Austin and Searle, Bourdieu further discovers that the force of speech acts is nothing more than institutional authorization. Whether or not the performative function of language is effective lies in whether the speaker is given an identity power, that is, whether he has the right to say valid discourses. An official naming or appointment has a strong authority given by the group to grant the named person a legal and widely recognized identity. Such an authority and class identity is to construct someone as an agent for speech acts in the social world through a system of duties, rather than through actions in their own name or authority. Authoritative discourses such as reports and sermons can not have their special effects or become a valid usage until they are recognized as authoritative discourses. Austin's and Searle's views on identity, status, and extra-linguistic institutions are also elevated to a sense of class and identity for Bourdieu. Social identity is a magical effect bestowed by the naming act and also a result and outcome of performative. For him, the real origin of the magic of Austin's and Searle's performative utterance mostly lies in the mystery of position or the authorization, which has helped and created this authority. In fact, the discourse itself does not have any "performativity" whatsoever, and it is the authority behind the language that gives it a certain "performativity". According to this view, authoritative discourses are only a model pattern, and its specific force mainly originates from its source of power; such a source exists in the produced and accepted institutional conditions, since the ability of using certain valid discourses exists only with authorization or at "authoritative" formal occasions. 


\section{Illocutionary Force And Conditions of Social Behaviour}

Moreover, Bourdieu highly approves of the concepts of "illocutionary force" and "force" etc proposed by Austin and Searle. As mentioned before, Austin proposed early on that speech acts have illocutionary force, while Searle explicitly and systematically puts forward the concept of "force". Bourdieu introduces the concept of illocutionary force into the research of social linguistic exchange, and for him, the language has a power to impose the social world and its differentiated valid opinions on people, i.e., the "illocutionary power" and the "the force to create the world". For him, the collective power is to construct a group through strengthening of behavior like common opinions and principles, so as to create the corresponding identity and power. At this point, he emphasizes that, "the most resolutely objectivist theory must take account of agents' representation of the social world”. Authoritative languages, such as reports and sermons, sometimes have the performative force even though they are not understood; even some heresy discourses (like witchcraft) has the "performative force of discourse" similar to that proposed by Austin. These kinds of illocutionary forces can produce specific social effects, such as orders, warnings, guarantees, apologies, and complaints. It can be discovered that Bourdieu has promoted the entire illocutionary force to the entire social level, and directly followed some analytic terms from Austin and Searle. He believes that there are still limitations in Austin's pragmatic analysis and his concept of "force". For example, Austin's pragmatic analysis is still limited to the analysis of linguistic performance competence inside the language, which is actually not complete. For him, the performative force or power of speeches does not, like that indicated by Austin, exist in "illocutionary expressions" or discourse words themselves, but comes from outside the language. That is to say, the authority of language comes from outside, rather than from inside the language. Even the force of some heresy discourses does not exist in the intrinsic force of language. Furthermore, the competence of symbolic power to influence the world does not exist in the form of expression and "symbolic system" of "illocutionary force". For him, the frequent practice of interpreting the performative force from the linguistic perspective or exploring the logic regularities hidden in linguistic habitus from it tends to make people forget that authority comes from outside the language. In fact, the language itself does not have such authority; it is only that the language represents or symbolizes such authority. Therefore, in Bourdieu's view, Austin's claim of finding the effectiveness of discourse from inside it is indeed a mistake.

Bourdieu accepts the somewhat-formalism analytical method in Austin's and Searle's speech act theory. As mentioned before, Austin, in his early life, measured and described discourses according to "true/false" conditions or standards, and judged performative discourses according to "felicity" or "infelicity" conditions or standards. Searle highly values researches into speech act conditions and standards, and the framework of his speech act theory is established on the basis of preparatory conditions, essential conditions, propostional contents and sincerity conditions. Bourdieu strongly agrees to Austin's introduction of "felicity conditions" for performative discourses. It should be said that, the introduction of this new evaluation dimension of "felicity/infelicity" can provide useful foundations for analysis of various legal acts and ethical code behavior. Bourdieu further introduces the standard of "felicity conditions" into specific real social relations and institutional acts for discussion, promoting the combined analysis of language and power. He accepts Austin's view that there is no true or false for "performative" speeches and further analyzes the two effectiveness or "felicity" conditions of class performative discourses: one is the greatness of "invisible power" or performative power possessed by the speaker at his assertion, and the other is the speaker's "expression of social status he has constructed" and his acquired constructed class identity the audiences recognize or mis-interpret, i.e., institutional identity. For him, the primary condition to make performative discourse successful is the felicity of speaker, i.e., the issue of his social function and discourse function; the satisfying condition of authoritative language is whether it can be understood and interpreted as authoritative language, under which it can display its special effect. 


\section{Speech Act Rules, Intentionality and Institutional Facts}

Bourdieu, in his economics of linguistic exchanges, highly values the research of linguistic market and regulation rules, which is somewhat attributed to the influence of Austin's and Searle's speech act theory. It is a highlight of Searle's speech act theory to focus on the research of speech act rules and condition. Bourdieu's economics of linguistic exchanges takes speech acts as its mediator, and it cannot be denied that it has referred to the research of linguistic rules and conditions. In fact, in his view, Austin's performative discourse can be judged to be "felicitous" or not "felicitous" only according to whether it respects certain "conventional procedures". Linguistic communications not only observe a set of superficial rules of linguistic symbols, but also follow a set of game rules more complex than the rules of linguistic exchanges, i.e., rules hidden in power competition of linguistic symbol communication. For Searle, speech acts are regarded as a speech act performed as per rules, and institutional facts are regarded as a system created and constructed according to rules, while this system is constructed based on the constructive rule of " $\mathrm{X}$ counts as $\mathrm{Y}$ in a context". For him, "the normativity is a consequence of the fact that the functional attribution situates the causal facts within a teleology". In Bourdieu's view, the language serves its purpose as a normative system, a specific law or examination institutional system, and influences the outside world so as to regulate various language practices. To be specific, language skills are not a simple technique ability, but a normative ability. In reality, even just an order or simply password can not serve its function until it is supported by the orders of things; the success of performative discourse act depends on the relations among all the rules constituting social orders. However, his theory of linguistic exchange has obviously added considerations of politics, power and economy etc to Searle's. He compares the rules of social linguistic exchanges to the rules of market economics. Similar to the governing of capital operation by market rules in the economic field, linguistic exchanges also observe some market rules and regulation rules. He intensively discusses class identity performative and its operational mechanism, and attempts to reveal how the identity of ruling class is generated and maintain the status of hierarchal ruling as well as how the identity of ruled class becomes "complicity" of effective performance of the ruling class.

There are many similarities between the theory of economics of linguistic exchanges and Searle's expounding of institutional facts and functional attribution, etc. Scholars such as Gunter Gebauer and Jennifer Marston William have made specific comparative study of social philosophy between Bourdieu and Searle. According to Searle, the primary step and link of institutional facts is functional attribution. Functions can be divided into no-actor functions, actor functions, and intentional functions; the functional attribution ability of the human beings is not simply natural functional ability, but an intentional function that grants status functions. By contrast, for Bourdieu, functional attribution can lead to normativity, and Searle's status function has become a symbolic capital for Bourdieu; intentional function attribution can not be achieved through physical properties of real objects, but through symbolic acts. Indeed, Searle highly emphasizes the symbolic function of language, and for him, "humans have the capacity to use one object to stand for, represent, express, or symbolize something else. It is this basic symbolizing feature of language that I take to be an essential presupposition of institutional facts". Searle's discussions also involve institutional facts, functions and power. For example, for him, "institutional reality is a matter of positive and negative powers, including rights, entitlements, honor, and authority, as well as obligations, duties, disgrace, and penalties”. Nonetheless, there remain a few differences from the strong political, class and identity elements in Bourdieu's theory. Bourdieu is in favor of Searle's research of background. In his view, time production is with experience as its premise, similar to Searle's premise of total background. Searle has made special discussion on the structure of institutional facts; correspondingly, Bourdieu has also explored in details the structure of linguistic market, for example, his division of factors affecting the market of linguistic exchange into extra-linguistic and intra-linguistic factors. Among them, intra-linguistic factors, such as discourse proficiency, discourse use ability, discourse use mentality and habitus, and style, etc. are all related to social status, history, experience, etc.; extra-linguistic factors include the legal structure, moral system, educational environment, social language exchange power, etc. 
Wacquant, in his An Invitation to Reflexive Sociology co-authored with Bourdieu, especially stresses that, Bourdieu's concept of “habitus” is close to Searle's concept of “intention in action”. In a certain sense, Bourdieu's concept of habitus is the concept of intentionality adopted by Searle, as both of them refer to the mode of connection to the outside real world and the cause of actions. For Searle, "intentionality is that feature of the mind by which mental states are directed at, or are about or of, or refer to, or aim at, states of affairs in the world. It is a peculiar feature in that the object need not actually exist in order to be represented by our intentional state”. For Bourdieu, habitus is collective individualization achieved through body embodiment, or collectivization of biological individuals realized through socialization. This point is also somewhat related to Searle's standpoint of biological naturalism. In general, both intentionality and habitus are with collective nature, but Bourdieu's concept of habitus emphasizes more the social and historical characters of this concept; their main differences are: firstly, habitus is with a stronger historical character, while Searle treats the historical character, amongst others, as a background element differentiated from intentionality; secondly, habitus is preconscious, while intentionality may be conscious, and for Searle, it is background that is preconscious; thirdly, Searle focuses more on the biological and natural characters of intentionality, which, for Bourdieu, is not so strong. For Searle, social reality, especially institutional facts, can often be interpreted as collective intentionality, functional attribution, and constitutive rules. By contrast, Bourdieu further combines language, society and power. During the construction of institutional facts, collective acceptance may lead to the exercise of power and the empowerment of status function; it also takes a long period of time to accept and recognize these status functions, and to grant the feasibility and desirability of power exercise.

\section{References}

[1] Gebauer G. \& and J. M. William. Habitus, Intentionality, and Social Rules: A Controversy between Searle and Bourdieu [J]. SubStance, Vol. 29, 68-83.

[2] Webb J.,T. Schirato \& G. Danaher, Understanding Bourdieu [M]. Crows Nest: Allen \& Unwin, 2002, 5.

[3] Bourdieu, P. Language and Symbolic Power [M]. Cambridge: Polity Press, 1991, 131, 234.

[4] Bourdieu, P. \& L. J. D. Wacquant. An Invitation to Reflexive Sociology [M]. Chicago: University of Chicago Press, 1992, 147.

[5] Searle, J. Mind, Language and Society: Philosophy in the Real World [M]. New York: Basic Books, 1999, 135, 154. 